\title{
The Impact of Disney's Entry into Shanghai and the Coping Strategies Jiang-Tao $\mathrm{LI}^{1, \mathrm{a}}$
}

No. 5 building, No.1 Zhongguancun Road, Haidian District, Beijing,China

ljt1108@163.com

Keywords:Disney,impact,theme park,strategies

\begin{abstract}
Nowadays,for the hot of Disney settled in Shanghai,this article has carried on the correlation discussion.Themain writing purpose of this article is for Disney settled in Shanghai brings a series of impactin social, economic, and cultural area, this paperprovidessome countermeasures and suggestionsfor government and the domestic theme park to deal with the impact, and in the hope of reducing the negative impact and expanding its positive effect.Firstly, this paper analyzed the impact of the social, economic and cultural aspects of Disney's entry into Shanghai.Then it analyzed the development status and existing problems of theme parks in China.Finally, based on the analysis of the above two aspectsthis articledevelopedsome relevant coping strategies for the government and the domestic theme park enterprises.
\end{abstract}

\section{Introduction}

June 16, 2016, Disneyland officially ${ }^{1}$ opened in Shanghai. As the world's number one cultural group, its industry covering food, accommodation, film, entertainment, theme parks and many other areas, Disneyland has become a carrier of cultural industries, and formed three platforms: large consumer platform, large cultural experience platform and large commercial operations platform. Disney's commercial operational capability and its commercial influence will be unprecedented. Therefore, it will be very important to analyze the impact of Disneyland's settling in Shanghai to our country and correctly formulate Countermeasures.

\section{First, the Impact of Disneyland's Settlingin Shanghai on China}

\section{The Social Impact of Disneyland's Settlingin Shanghai on China}

With the rapid economic development and the rapid improvement of people's living standards, people's demands for high-end culture entertainment projects continue to increase. The project of Shanghai Disneyland set entertainment, ornamental, leisure, education, experience and other functions in one, to meet people's demand for high-level cultural tourism. At the same time, it provides a high level of management standards and high quality service standards for the operation of the domestic theme parks. It will be sure to affect and promote the domestic theme parks and the high-end services' development.

However, that Disneyland settled in Shanghai will also bring a strong impact on China's society, mainly in the following three aspects:

(1) The Predatory Development of High-End Tourism Resources Will Lead to the Imbalance of China's High-End Market.Disneyland settled in Shanghai, on the one hand, advantages of its cultural tourism aircraft carrier, such as the tourism and entertainment project design system, adept commercial operation skills and a high level of service and management, must be to form a siphon effect on the high-end tourism customer resources around Shanghai and even the whole country generated predatory exploitation.

On the other hand, the domestic theme parks' small windsurfing operating status will exacerbate their operating pressure to attract high-end customers, and the resulting reduction in passenger

\footnotetext{
${ }^{1}$ Author: JiangtaoLi,male,born in Yantai, Shandong Province in1966,Beijing Academy of social sciences, associate research fellow, No. 33 North Fourth Ring Road, Chaoyang District, Beijing,100101. Research direction: Management Science and Engineering, Business model research.
} 
traffic and decline in performance, may be to change the existing domestic theme park development pattern, thereby forming the unbalanced situation of Chinese high-end tourism market in the future.

(2) Impact on the Social Ecology of ShanghaiFirst is to increase the employmen ${ }^{2} t$ opportunities in Shanghai at the same time lead to lower employment in other industries. Due to the huge resources of Shanghai-Disneyland, the theme park hotel, catering, entertainment, retail and other facilities construction, will undoubtedly bring great opportunities for employment, create at least five million jobs for the local, as well as a reduction of employment rate in other areas.[1]

Second is to increase the pressure of life of residents in Shanghai. The operational of Shanghai-Disneyland requires a large number of foreign workers, therefore will bring a lot of traffic, which would disturb public order, increase traffic congestion, inconvenience to the surrounding residents, thus increasing people's daily life stress.[2]

Third is to limit the development of the surrounding tourism projects. Occupying a lot of land for the project, a negative impact of the development and operation of comprehensive industrial projects in Shanghai-Disneyland will be on the original perimeter of the tourism industry, tourism projects to be built and unbuilt projects. What's more, Disneyland on the surrounding environment has many restrictive clauses, such as the height of nearby buildings, use of nearby land, limit aircraft flying over the theme park and so will adversely affect the local economy.[2]

(3) Impact on People's Psychological State-Owned Tourism Brand Awareness.As the management and service levels in the short term domestic theme parks difficult to quickly improve, as also the comprehensive ability of commercial operations hard to enhance, in strong contrast to promote, will increase people's contempt for the state-owned brand, which complained or even deny the depth of domestic low-end tourism services, and thus impacting the traditional business ecology and ecological economics of China.

\section{The Impact of the Disneyland Settling in Shanghai on China's Economy}

(1) Not only Disneyland Settled in Shanghai Stimulating the Local Economic, but Also Improving the People's Living Standards. Disneyland has 330 million consumer groups in the 3-hour range, the first phase of the park covers an area of 1.3 million square meters. Such a land-intensive, capital-intensive and labor-intensive consumer space, is bound to bring a large role in promoting economic development in Shanghai and raise the living standards of the local residents. Further, as Disneyland's real estate properties, the impact of this development is sustainable[3]

(2) Disneyland Project in Shanghai can Stimulatethe Local Cultural Innovation Capacity. On the one hand, it can increase the cultural industry chain needs, which would bring enormous business opportunities for a lot of industries, such as franchised toy production, advertising, publishing and printing, cable television, internet, animation, etc. At the same time, such a mature cultural model is conducive to stimulate and enhance the cultural innovation ability of Shanghai, improving the environment of cultural industry development.[4,5]

(3) Disneyland's Strong Radiation Effect on Our Economy. Disneyland settled in Shanghai in 2016, it is expected to attract tourists reached 10 million scale, later every year added to the new tourist accommodation of Shanghai of 500--000 million. By 2020, the annual tourist accommodation of Shanghai-Disneyland is expected to exceed 15 million people. Such a large scale tourism resources platform is bound to drive the strong development of tourism, catering, hotels, transportation and other service industries in Shanghai, while making a tremendous radiation impact on the relevant industries in the surrounding areas, especially in Yangtze River Delta region — the Pan Disney Area, and the surrounding tourism resources will also benefit from the amount of tourists attracted by Shanghai-Disneyland.[6]

(4) Stimulating Economic Development in Shanghai and its Surrounding. As we known, tourism is a strong industry association industry, according to relevant statistics, tourism revenue growth of

\footnotetext{
${ }^{2}$ Author: JiangtaoLi(1966-),male,Beijing Academy of social sciences, associate research fellow, No. 33 North Fourth Ring Road, Chaoyang District, Beijing,100101. Research direction: Management Science and Engineering, Business model research.
} 
one yuan, will bring relevant industry revenues increased by 4.3 yuan. Therefore, Shanghai-Disneyland in Shanghai led to the development of tourism, but also led to the development of other industries. And the visitors to Disneyland usually have strong purchasing power, therefore, is bound to stimulate economic development in Shanghai and East China.[7]

(5) Cause House Prices in the Surrounding Areas of Shanghai Rose.The settling in Shanghai of Disneyland will result in further increases in housing prices, housing prices in the surrounding area overnight from 3,000 yuan / square meter rose to 16,000 yuan / square meter. Despite the Government increased taxes, it's only enriched the pockets of the real estate business, for ordinary people, it means endless pressure, which resulting in a series of negative effects to the national economic security, such as more serious real estate bubble.[7]

(6) Impact and Challenges to the Management of Local Theme Parks. The construction of Shanghai-Disneyland is conducive to the adjustment of economic structure and development of local economic, what it brings to a country is competition for the country's cultural and economy. By displaying and integration culture, the ability to mass cultural operations be formed, which will bring huge profits. To the contrary, the local theme parks indulge in shoddy and imitating each other, coupled with the single rides and lack of cultural context and meaning, led themuncompetitive, in turn further exacerbate the situation of poor management, low level of tourists and earnings.

\section{The Impact of Disneyland Settling in Shanghai on China's Culture}

With the rapid increase of China's economy and the rapid improving of people's living standards, the requirement for high-end culture entertainment continues to improve. Shanghai-Disneyland appears to meet the needs of the people for high-level cultural tourism projects, but also to be able to improve the operation and service level of cultural entertainment products which focus on the development of the theme park, and promote the development of the whole industry.

(1) Reflecting the Soft Power of National Culture and Improving the Quality of People's Cultural Life.Spent six years to build and a total investment of about 34 billion yuan, there is no doubt that Disneyland has become the symbol of the national cultural soft power and global consumption in cultural industry. The Disney culture can improve the quality of people's life by a rich variety of adventure, entertainment and exciting projects, through which can tip people's points of interest and improve the quality of entertainment cultural life to significantly improve their lives.

(2) With the Gradual Infiltration of Disney Culture in China, Disney Culture Caused a Certain Extent of Impact on the Local Culture.As Disney penetrate into China, people totally immersed in the Disney atmosphere which the core is American culture during the process of a variety of services and pleasure, resulting in that people gradually accepted, recognized or even aspire to Western culture, ultimately to China's traditional culture and national spirit of an impact.

(3) Influence on the Development and Dissemination of National Cultural Brand. Since still immature in use of resources and operating management, we will face enormous pressures and challenges confronting with the powerful culture enterprise aircraft carrier of America. As dominant cultural enterprises, Disney competes directly with local enterprises for consumers after entering the Chinese market, making a direct impact on the development of local culture and the brand influence.

(4) Impact on the Values of Chinese Culture from Disney Culture. The huge transmission power in culture and the ability to agitate the soul and experience will inevitably shock our culture value, thus eroding and taking possession of our culture. The adventurous children which Disney's main consumer are accustomed to the culture, the lifestyle, the way of thinking, the value system of America, all that reinforces the American values. Meanwhile, for the adults, they may belittle the Chinese culture in their subconscious once contacted with the great advantage of Disney's American culture.

(5) Disney Culture to Some Extent Contributed to the Tendency of Xenophilia. As the domestic theme parks too late to improve management and facilities, the high-quality services and high-level management of Disney may increase the masses' negative sentiment on the domestic parks which in turn exacerbates theirs worship of American culture, such as belittle, blame and contempt. 
(6) The Government Showed Some Degree of Prudence to the Disney Culture. Worried about the potential impact on Chinese local culture from Disney, the government refuses to take in the Chinese Disney Channel settled in Shanghai in order to minimize the potential impact and adverse effects to our culture form Disney .

(7) The Significance of Disney Culture to the Development of Our Culture. In view of Disney's transcendental capacity for propagating and integrating, we should also consider to build a complete value chain of cultural industry on the basis of China's excellent culture for thousands of years which symbolizes cultural soft power. To be recognized in the world, we could also build some Chinese-style Disneys in other counties so that the national culture with Chinese characteristics can be spread worldwide.[8]

\section{Second, the Development Status of Theme Parks in China and the Problems}

Theme park rapid development in China, but due to increasing competition, business parks improper question, and now most of the domestic theme park at a loss or barely support of health For the current situation and development of China's theme park their problems as follows:

\section{The Development Status of Theme Parks in China}

(1)The tremendous demand for culture and entertainment and vast potential of domestic theme park market. Now, China is stepping into a stage characterized by the rapid growth of culture and entertainment consumption. According to the statistics, total domestic passenger tourist attraction for about $7 \%$ annually since 2000, and reached nearly 14 million passengers in 2010. In short, the huge domestic theme park market not only to provide consumers with a large consumer platform and cultural experience platform, but also for cultural enterprises to provide a large-scale commercial operation platform.

(2) Leading enterprises developed rapidly while the overall level is low. Among the 2015 top ten theme parks Group, China accounted for three seats, they are ranked seventh in Changlong Group, ranks eighth HuaqiangInfante with a ranking first growth rate of $77.4 \%$ in the world and ranked tenth Songcheng Group. But, in addition of a few leading enterprises, domestic theme parks are widespread confronting the problems of low degree of market and poor economic inefficiency. By 2009, $70 \%$ of all enterprises were at a loss, $20 \%$ were fair, only about $10 \%$ were earnings, which reflected the overall low level of development.

(3) Industry competition tends to be international and hot. As Disneyland settled in Shanghai, Universal Studios, Epcot, Paramount and other international brands have landed in China one after another which led to increasing international competition between domestic theme parks. All that is inevitably will results in more intense competition in the domestic market in which gradually become the competition between brands and business models.

\section{The Problems Existing in the Development of Theme Parks in China}

Overall, the development of domestic theme parks is still confronting with many problems, such as large amount, various types and small-scale operations, now analyzed as follows:

(1) Inaccurate market positioning. Since domestic theme parks started late and lacked of theoretical and practical experience extremely, they can only imitate the large theme parks abroad in a superficial way, or to put it another way, they are lacking of accurate market positioning. Embarrassingly, most domestic parks are only providing functions of basic viewing and playing, can't meet the huge market demand for culture, experience, interactive, high-tech and high-quality tourism product, resulting in low customer revisit rate and poor performance of enterprise operation revenue, efficiency and effect.

(2) Inaccurate industry positioning. In demand of spiritual and cultural products with a rapid growth rate, the evaluation criteria improved gradually, too. Those Ornamental amusement parks with small scale and single function are no longer in line with industry trends. Sadly, the majority of our parks do not recognize the problem. As mentioned above, the problems of inaccurate industry positioning, low capital participation, low market concentration, low level of industrialization, all of these together resulting in a small, scattered and chaotic management situation, in which difficult to 
form intensive and large-scale competitiveness, thus hard to survive in an increasingly competitive market.

(3) Lack of distinct themes and cultural connotation construction. Theme is the soul of the theme park, while most of domestic theme parks are only simple to follow and imitate, resulting in lack of distinct themes. In addition, they are so similar in recreational facilities and architectural style that hardly to achieve their purposes of echoing themes, rendering atmosphere and creating novel experiences. What's more, most domestic theme parks are so simple in content setting that easy to lose tourists' interest, resulting in a dramatic reduction in tourist resources and unsustainable operations.

(4) A single profit model and incomplete industrial chain. Compared to Disneyland's tickets income accounted for only $30 \%$ of the total profit, most of domestic theme parks' tickets income accounted for $80 \%$ of the total profit. It's no doubt that the single profit model in a large extent restricts the development of domestic theme parks, unable to drive catering, accommodation, shops and other related industries to build industry chain.

(5) lack of innovation service awareness and sustainable development. Most domestic theme parks early in the project is not ready for long-term development planning, coupled with various management problems of slow updated project, difficult function upgrades and old recreational facilities, the tourist source of domestic theme parks is gradually shrinking and fading. The average life span of most theme parks is only three to five years, indicating a weak capacity for sustainabledevelopment.

\section{Third,Countermeasures and Suggestions on the Development of Theme Parks in China}

Through the analysis of Disney settled in Shanghai's influence on China's society, economy and culture and the development status and problems of domestic theme parks, now we put forward relevant suggestions for the development of domestic theme parks from the perspective of government and enterprises.

\section{Policy Recommendations for the Government}

(1) Strengthening the behavior supervision of Disneyland in China. Disneyland is a huge cultural industry group with a distinctive American culture and a large number of America cultural symbols whose settling in Shanghai brought a different degree of impact on our society, economy and culture. Therefore, the government should carry out strict supervision and management of the industrial development of Disneyland, and limit its expansion in China. Specifically includes the following two aspects: on the one hand, strengthen the supervision of local theme parks' behavior of disorderly operation and homogeneous competition, set standards in terms of market access and audit rules, reduce waste of resources. In the matter of regulation and ex post regulation, change the paradigm of government governance by means of cooperative regulatory or collaborative governance, making full use of the strength of enterprises, non-governmental organizations, the media and the public. In addition, the government should decentralize its part of administrative authority. By establishing mechanisms for effective communication and rapid match between supply and demand among theme park enterprises and tourists, coupled with a reasonable guide and full use of the influence of media and public on information disclosure and supervision, to ensure that market orderly and healthy development. On the other hand, guard against the development of foreign invested theme park enterprises in China, especially involved in the fields of China's economy and culture security, which need to maintain a high degree of vigilance. For example, we can set more stringent market access mechanism, close attention to its operational strategy and supervision, regularly assess its development in China and social impact, etc. In a word, we should maintain a proper balance between the protection of local development and encourage open innovation, supervision of Disney's cultural transmission, predatory development of domestic resources and its industrial chain expansion, and increase the protection of cultural resources in our country, the characteristic of Chinese culture to infiltrate to the Disney, guide and promote the realization of Disney's Chinization.

(2) Foster the development of the domestic carrier-class cultural enterprises. The best way to deal 
with Disney's cultural strategy is to build up a group of domestic carrier grade cultural enterprises. Drawing on the model of high speed railway, the government can make 1:1 copy of Disneyland, promote the growth of a number of cultural giants and entertainment giant in the capital market.

(3) Promote the brand industry operation of large enterprises. For the large-scale theme park enterprises, the government should for financial support to promote them to take the road of brand development and fully develop their brand value, push industry operation. In short, to create a group of influential local culture industry brand.

(4) Promote the construction of enterprise management system. The development of domestic theme parks, more is due to its extensive mode of operation and management. Government should actively guide and create conditions for enterprises to learn Disney advanced management experience and business models, together with the research of experts and scholars and practical development experience of enterprises, construct a set of management system with Chinese characteristics, and promote them.

(5) Speeding up the construction of talent training system in theme park. At this stage, China has a large number of theme parks while the management talent is extremely scarce. Adding that we have not established a special tourism operation personnel training system at present, therefore, the government should accelerate the theme park personnel training system through training a number of professional talents in theme park planning, designing, construction, management and operation, to promote domestic theme parks to achieve high efficiency and external expansion.

(6) Promote the integration of the industrial chain of theme parks in china. Disneyland is not just a theme park, it is embodied in the concept of cultural industry giant whose industries covers theme park, movie, catering, hotels, real estate, as well as books, printing, souvenirs, training, consulting and output management. In other words, what it composed of is a huge industrial system. While in domestic theme park market, despite of several leading theme parks as HuaqiangInfante, OCT(overseas Chinese town), Songcheng and other enterprises related to film and television animation, catering, real estate and several other industries, what the vast majority theme parks provided are just amusement parks for sightseeing and viewing with the main character as a short industry chain and a single profit model. It's difficult for them to achieve leapfrog development. The feasible way for government to promote a rapid growth of theme parks is to accelerate the rectification of some amusement parks, promote the industrial transformation and upgrading, push the development of peripheral industries such as catering, accommodation, images, books, extend and integrate the industry chain etc.

(7) Strengthen the government's macro-control, especially in the terms of theme park project application review. The government should strengthen macro-control and guidance of enterprises in construction sites, sources of funding, cultural declaration and other aspects to avoid blind investment and enclosure behavior under the banner of theme park.

\section{Countermeasures and Suggestions for Theme Park Enterprises}

(1) An accurate market positioning. The main reason for Disney's success is rely on its creative themes helped to promote tourism products. In contrast, most theme parks in China are lack of the crucial themes, because the determination of themes needs a clear market positioning and dynamic business evaluation and multi argument to a series of basic market conditions in the area to be developed, such as economic strength, population status, cultural tradition, consumption level, park coverage and transportation network, etc.

(2) Establish a reasonable ticket price system as developing a diversified profit model. Theme park to grow and develop can't be too dependent on ticket revenue. Instead, they should make reasonable ticket price system through developing a multivariate profit model. In addition, closely integrate the park with restaurants, hotels, shops, books and other industries to achieve commercial operation, as well as extending the customer stay in parks, driving the development of peripheral industries, expanding the industrial chain and diversify earnings.

(3) To dig deep into the traditional culture of our country and construct the deep cultural connotation of theme park. Just as the deep cultural connotation is the vitality of theme park, 
Songcheng's success comes from the deep excavation and display of Chinese ancient culture. China has a history and civilization of 5,000 years, based on what formed a profound traditional culture whose heritage is our precious cultural resources. The domestic theme parks should fully rely on our rich cultural resources, combined with the theme of the park, to build a deep cultural connotation to meet people's demand for high-quality cultural products.

(4) Innovative service content to achieve sustainable development. Disney's success stems from its "never built up the Disney" slogan and continuous creation and update. Disney's project management is one of "three-three system", that is, every year to eliminate $1 / 3$ expired project and establish 1/3 fresh project to ensure visitors a different sense of freshness every time. Similarly, we also need to focus on the innovation and upgrade of park facilities and services in order to achieve sustainable development of the park.

(5) Focus on the development of high-tech products and original IP implants. Given that the development trend of theme park is high-tech park, wisdom park and cultural park, high-tech product development and implantation of the original IP for theme parks is an important part of the development of cultural industry giant, which point powerfully illustrated by Disney and Huaqiang Infant's success. Therefore, if the domestic theme park enterprises want to become bigger and stronger they must pay attention to the development of high-tech products and the original IP, thus forge the enterprises' core competitiveness on which to build up a giant cultural industry.[9]

(6) people-oriented, focusing on human services and reflecting the human care. Humanized service has been the soft underbelly of domestic theme parks. The so-called humanization, mainly reflected in the design of project function and personalized service, that is to fully reflect the needs of customers in the design of entertainment projects. Disneyland's success mainly lies in its close to the market and needs of all tourists to the main, perfectly reflects its full service concept of humanity and warmth. The domestic theme parks should learn from this service concept, greatly improve their service level.[10]

(7) Actively expand investment and financing channels to promote the sustainable development of enterprises. Development of large-scale cultural industries cannot do without the support of the capital. Theme parks should be good at the use of corporate listing and all kinds of innovative financing channels to raise funds for the sustainable development of enterprises.

\section{Summary}

The main conclusions of this paper are the following two points:

1.Disney's entry into Shanghai has some adverse effects and beneficial effects on the social, economic and cultural aspects of China.For the adverse impact,government should strengthen the supervision and macro-control, reasonable limit its development and avoid the social risks.For the favorable side,the government can properly encourage and guideto achieve Disney china.

2.Through theanalysis of the impact of Disney in Shanghai on China's economic, social and cultural, combined with the present situationand existing problems of the theme park in China, this paper from both the government and enterprises puts forward some corresponding strategies.It is necessary for the government to strengthen supervision,for the enterprise to learnDisney's successful management experience is an important way to speed up itsdevelopment .

\section{References}

[1]YuanyuanZhi,The influence of Disney park on the development of tourism in Shanghai: submitted to Journal ofChangSha University 29,3(2015)

[2]Runze Mao, Study on the problem and Countermeasure of the multiple effects of Disney Park in Shanghai: submitted to Journal ofEastChinaEconomicManagement,24,10.(2010)

[3]ZengxianLiang,JigangBao, Development of large theme parks and employment of urban residents: submitted toJournal of Tourism Tribune,29,8.(2014) 
[4]MengjieWei,FanglanWu,Yuchen Zhu, Detailed Shanghai Disney feast, Five major industry is expected to benefit,Shanghai Securities News,5,11(2009)

[5]ZhenguoZhang,XueliLi,Tingfang Tao, The influence of Disney project on the development of service industry in Shanghai : submitted toJournal of Modern Management Science(2013)

[6] Haitian Huang, Study on the pulling effect of Shanghai Disney on the tourism industry of Yangtze River Delta, Special Zone Economy,1(2011)

[7] Yuheng Wang, Talking about the advantages and disadvantages of Disney in Shanghai,5,4(2010)

[8] Hongyan Zhang, What does the Disney culture bring to us--Five reflections on the construction of Chinese culture

[9] Information on http://house.china.com.cn/commercial/view/840110-2.htm

[10] Xing Hou, Disney's Enlightenment to the development of theme parks, China Travel News(2015)

[11] HongbaoLi,Theoretical and empirical research on the innovation and development of domestic theme parks:submitted to Journal of Suzhou University of Science and Technology(Social Scienc),32,6(2015)

[12] XuanzhiYang, The Problems and Solutions of the Cultural Theme Park's

Construction from the Perspective of Cultural Industry $\mathrm{R}$.evitalization:submittedtoJournal of Qiqihar University(2015)

[13] Information onhttp://tj.winshang.com/news-580019.html 